(RESEARCH ARTICLE)

\title{
Effect of cellulolytic Ruminococcus albus KU-F152 and non-cellulolytic Selenomonas ruminantium S137 supplementation on feedlot performance, carcass characteristics and meat quality of Holstein crossbred steers
}

\author{
Hattakum Chonnpat 1,2, Wongchawalit Jintanart ${ }^{3}$, Thirawong Prayad ${ }^{1}$, Boonsaen Phoompong ${ }^{1}$ and \\ Sawanon Suriya ${ }^{1, *}$ \\ ${ }^{1}$ Department of Animal Science, Faculty of Agriculture at Kamphaeng Saen, Kasetsart University, Nakhon Pathom 73140, \\ Thailand. \\ 2 Department of Agriculture Technology, Faculty of Agriculture Technology and Industrial Technology, Nakhon Sawan \\ Rajabhat University, Nakhon Sawan 60000, Thailand. \\ ${ }^{3}$ Department of Microbiology, Faculty of Liberal Arts and Science at Kamphaeng Saen, Kasetsart University, Nakhon \\ Pathom 73140, Thailand.
}

Publication history: Received on 24 June 2020; revised on 05 August 2020; accepted on 06 August 2020

Article DOI: https://doi.org/10.30574/wjarr.2020.7.2.0228

\begin{abstract}
The effect was determined of cellulolytic Ruminococcus albus KU-F152 and non-cellulolytic Selenomonas ruminantium S137 on the digestibility, feedlot performance, carcass characteristics and meat quality of Holstein crossbred steers. Eight steers were randomly inoculated with $R$. albus KU-F152 and S. ruminantium S137, and eight steers were used as the non-inoculated control. The steers were fed a Total mixed ration (TMR) diet (21:79 ratio of corn silage and concentrate) that was offered ad libitum for 6 months. The results showed that the inoculation of R. albus KU-F152 and $S$. ruminantium S137 had no positive effect on the growth performance of Holstein steers; however, the inoculation increased the feed conversion ratio (FCR) compared with the control. The ruminal fermentation results demonstrated that $R$. albus and $S$. ruminantium inoculation significantly increased total volatile fatty acid (VFA), levels and increased the marbling score of meat as carcass characteristics. Regarding meat quality characteristics, $R$. albus and $S$. ruminantium inoculation increased the meat fat and reduced the thawing loss. Furthermore, the meat of the treatment group had a significantly lower shear force (tender meat) and a lighter colour than that of the non-inoculated control.
\end{abstract}

Keywords: Dairy steers; Feedlot; Meat quality; Bacteria supplementation; Ruminococcus albus KU-F152; Selenomonas ruminantium S137

\section{Introduction}

Rumen bacteria play important roles in digesting feed, especially the fibre, by increasing the solubility of crystalline cellulose [29]. Cellulose is the most abundant component of plant cell walls [20]. Fibrous feed is the main energy source for ruminants and has an important role in the development of calf digestive organs [9]. The digestibility of cellulose was improved by the introduction of highly cellulolytic strains of bacteria in the rumen and cellulolytic bacteria belonging to the Fibrobacter succinogenes, Ruminococcus flavefaciens and R. albus groups [20]. However, cellulolytic bacteria will interact synergistically with non-cellulolytic bacteria, and Sawanon and Kobayashi [27] and Sawanon et al. [28] found that non-cellulolytic Selenomonas ruminantium improves fibre digestion when co-cultured with $R$. flavefaciens or F. succinogenes. Piamya et al. [24] found that co-culture of $R$. albus KU-F152 and S. ruminantium S137 resulted in a higher dry matter (DM) and Neutral detergent fiber (NDF) digestibility of fibrous feed compared with monoculture. Other studies have demonstrated the cellulolytic interaction of various bacterial combinations, such as $R$. flavefaciens or $F$. succinogenes, with non-cellulolytic $S$. ruminantium or P. ruminicola $[14,27,28]$. These researchers reported an interesting relationship between non-cellulolytic bacteria and cellulolytic bacteria in ruminal fibre

\footnotetext{
${ }^{*}$ Corresponding author: Sawanon Suriya
} 
degradation, as non-cellulolytic bacteria species can activate cellulolytic bacteria through nutritive interactions, including hydrogen transfer, ammonium, vitamin or cellulose gene expression as cross feeding of degradation and fermentation products derived from plant fibre $[14,16]$. Wolin et al. [30] reported that cellulolytic bacteria such as $F$. succinogenes, $R$. flavefaciens and $R$. albus produced succinate during fibre digestion, and non-cellulolytic $S$. ruminantium converted succinate (succinate-decarboxylation) into propionate. The propionate is used in the cattle liver for glucose production, with the glucose from propionate being the preferred substrate for deposition of intramuscular fat, such as marbling, a key component in determining meat quality grade [10]. In addition, non-cellulolytic bacteria can reduce the negative effects caused by rapid ruminal fermentation of feed with a high concentrate ratio, which results in a $\mathrm{pH}$ decrease due to the accumulation of organic acids in the rumen and a shift in the delicate balance of rumen microorganisms [19]. The growth of cellulolytic bacteria is inhibited at a ruminal pH below 6.0, and the lactate-producer bacterium, Streptococcus bovis, is replaced instead by Lactobacillus spp. at a ruminal pH below than 5.4, causing excess lactate accumulation and cow death from acidosis. Lactate-utilizing bacteria, such as Megasphaera elsdenii and $S$. ruminantium S137, begin to proliferate in response to lactic acid accumulation and remove it by converting it to volatile fatty acids (VFAs) that can be absorbed in the rumen [28, 32].

Furthermore, the inoculation or supplementation of rumen bacteria in rearing cattle may increase performance, such as feed intake, feed conversion and body weight $[11,15]$. While the inoculation of rumen bacteria could increase the feed intake of Holstein caves during the weaning period [26], few studies have reported the effect of inoculation of rumen bacteria on performance. However, there has been no report on bacterial application in feedlot Holstein steers. Therefore, the objective of this experiment was to evaluate the effect of cellulolytic $R$. albus KU-F152 and non-cellulolytic S. ruminantium S137 supplementation on the feedlot performance, carcass characteristics and meat quality of Holstein steers.

\section{Material and methods}

\subsection{Bacterial and basal media preparation}

Cellulolytic $R$. albus KU-F152 from buffalo rumen [5, 25] and non-cellulolytic S. ruminantium S137 from sheep rumen [27] were used .R. albus KU-F152 was pre-cultured in $10 \mathrm{~mL}$ basal medium containing cellulose and cellobiose at $0.5 \%$ $(\mathrm{w} / \mathrm{v})$ as carbon sources under anaerobic conditions for maintaining bacteria. One hundred millilitres of basal medium were prepared with the following composition :7.5 mL of mineral solution I $\left(0.6 \mathrm{~g}\right.$ of $\mathrm{K}_{2} \mathrm{HPO}_{4}$ in $100 \mathrm{~mL}$ of distilled water) and mineral solution II (1.2 g of NaCl, $1.2 \mathrm{~g}$ of $\left(\mathrm{NH}_{4}\right)_{2} \mathrm{SO}_{4}, 0.6 \mathrm{~g}$ of $\mathrm{KH}_{2} \mathrm{PO}_{4}, 1.2 \mathrm{~g} \mathrm{of} \mathrm{CaCl}_{2}, 0.25 \mathrm{~g}$ of $\mathrm{MgSO}_{4} \cdot 7 \mathrm{H}_{2} \mathrm{O}$ and $100 \mathrm{~mL}$ of distilled water), $0.1 \mathrm{~mL}$ of $0.1 \%$ resazurin, $0.1 \mathrm{~g}$ of L-cysteine- $\mathrm{HCl} \cdot \mathrm{H}_{2} \mathrm{O}, 0.2 \mathrm{~g}$ of bactopeptone, $0.12 \mathrm{~g}$ of yeast extract, $0.5 \mathrm{~g}$ of glucose, $0.5 \mathrm{~g}$ of cellobiose, $30 \mathrm{~mL}$ of clarified rumen fluid, and $50 \mathrm{~mL}$ of distilled water, and the $\mathrm{pH}$ was adjusted to 6.8 with $1 \mathrm{~N} \mathrm{NaOH}$ before addition of $5 \mathrm{~mL}$ of $8 \% \mathrm{Na}_{2} \mathrm{CO}_{3}$ [28]. After incubation at $38{ }^{\circ} \mathrm{C}$ for $24 \mathrm{hr}$, $2.5 \mathrm{~mL}$ of $R$. albus KU-F152 suspension was propagated in $250 \mathrm{~mL}$ of the same basal medium at $38{ }^{\circ} \mathrm{C}$ for $24 \mathrm{hr}$ and adjusted to an optical density (OD) of $0.5\left(3.85 \times 10^{7} \mathrm{CFU} / \mathrm{mL}\right)$ with anaerobic dilution solution for inoculation [27]

S. ruminantium S137 was pre-cultured in $10 \mathrm{~mL}$ basal medium containing $0.1 \%(\mathrm{w} / \mathrm{v})$ glucose.One hundred millilitres of basal medium were prepared with the following composition :7.5 mL of mineral solution I $\left(0.6 \mathrm{~g}\right.$ of $\mathrm{K}_{2} \mathrm{HPO}_{4}$ in 100 $\mathrm{mL}$ of distilled water) and mineral solution II (1.2 $\mathrm{g}$ of $\mathrm{NaCl}, 1.2 \mathrm{~g}$ of $\left(\mathrm{NH}_{4}\right)_{2} \mathrm{SO}_{4}, 0.6 \mathrm{~g}$ of $\mathrm{KH}_{2} \mathrm{PO}_{4}, 1.2 \mathrm{~g}$ of $\mathrm{CaCl}_{2}, 0.25 \mathrm{~g}$ of $\mathrm{MgSO}_{4} \cdot 7 \mathrm{H}_{2} \mathrm{O}$ and $100 \mathrm{~mL}$ of distilled water), $0.1 \mathrm{~mL}$ of $0.1 \%$ resazurin, $0.1 \mathrm{~g}$ of L-cysteine- $\mathrm{HCl} \cdot \mathrm{H}_{2} \mathrm{O}, 0.2 \mathrm{~g}$ of bactopeptone, $0.12 \mathrm{~g}$ of yeast extract, $0.1 \mathrm{~g}$ of glucose, $30 \mathrm{~mL}$ of clarified rumen fluid, and $50 \mathrm{~mL}$ of distilled water, and the $\mathrm{pH}$ was adjusted to 6.8 with $1 \mathrm{~N} \mathrm{NaOH}$ before addition of $5 \mathrm{~mL}$ of $8 \% \mathrm{Na}_{2} \mathrm{CO}_{3}$ [28]. After incubation at $38{ }^{\circ} \mathrm{C}$ for $4 \mathrm{hr}$, $2.5 \mathrm{~mL}$ of $S$. ruminantium S137 suspension was propagated in $250 \mathrm{~mL}$ of the same basal medium at $38{ }^{\circ} \mathrm{C}$ for $4 \mathrm{hr}$ and adjusted to $0.5 \mathrm{OD}\left(4.25 \times 10^{7} \mathrm{CFU} / \mathrm{mL}\right)$ with anaerobic dilution solution for inoculation [27]

\subsection{Animals, experimental design and feeding}

The experiment was conducted at the Ruminant Research Unit, Department of Animal Science, Faculty of Agriculture at Kamphaeng Saen, Kasetsart University, Nakhon Pathom, Thailand. Sixteen Holstein crossbred steers with an average age of 18 months (mean live weight \pm standard deviation, $448.61 \pm 51.50 \mathrm{~kg}$ ) were vaccinated against foot and mouth disease, and dewormed to remove endo- and ectoparasites. The steers were kept in individual pens $(3.0 \times 4.5 \mathrm{~m})$. Then, eight steers were randomly inoculated with $250 \mathrm{~mL}$ of $R$. albus KU-F152 and $250 \mathrm{~mL}$ of S. ruminantium S137 using an anaerobic technique at 14 days intervals. Eight steers were supplemented with $500 \mathrm{~mL}$ of medium without bacteria medium as the control. 
The steers were fed a TMR diet (Table 1) ad libitum for 6 months. The diet was provided twice per day (07.00 AM and 16.00 PM). The experiment lasted 184 days. At the end of the study, all steers were deprived of feed but allowed free access to water. The steers were housed in collective pens for approximately $12 \mathrm{hr}$.

Table 1 Ingredient composition and nutrient content of TMR diet

\begin{tabular}{|c|c|}
\hline Item & Amount \\
\hline \multicolumn{2}{|l|}{ Ingredient of TMR diet, \% dry matter } \\
\hline Corn silage & 21.19 \\
\hline Molasses & 6.63 \\
\hline Urea $(46-0-0)$ & 1.50 \\
\hline Cassava chip & 30.00 \\
\hline Expeller pressed palm kernel meal & 20.90 \\
\hline Soybean meal (44\% CP) & 7.85 \\
\hline Ground corn & 10.11 \\
\hline Premix for beef cattle ${ }^{1}$ & 0.50 \\
\hline Sulphur & 0.30 \\
\hline Salt & 0.50 \\
\hline Dicalcium phosphate P-18 & 1.20 \\
\hline Sodium carbonate & 0.10 \\
\hline \multicolumn{2}{|l|}{ Nutrient content of TMR diet, \% dry matter } \\
\hline Crude protein & 14.78 \\
\hline Crude fat & 1.26 \\
\hline Crude fibre & 17.21 \\
\hline Ash & 6.78 \\
\hline Calcium & 0.75 \\
\hline Phosphorus & 0.47 \\
\hline NDF & 42.92 \\
\hline $\mathrm{ADF}$ & 24.57 \\
\hline NFE & 56.97 \\
\hline TDN & 66.98 \\
\hline Gross energy (GE) Mcal/kg & $3,236.32$ \\
\hline
\end{tabular}

1 Vitamin A = 2,160,000 IU, vitamin B3 = 100,000 IU, vitamin E = 5,000 IU, Mn = 8.5 g, Zn = 6.4 g, Cu = $1.6 \mathrm{~g}, \mathrm{Mg}=16 \mathrm{~g}, \mathrm{Co}=320 \mathrm{mg}, \mathrm{I}=800 \mathrm{mg}$, $\mathrm{Se}=32 \mathrm{~m}$

\subsection{Performance determination}

Dry matter intake (DMI), average daily gain (ADG) and the feed conversion ratio (FCR) were measured to obtain animal performance data.DMI was measured by the difference between steer weights before successive feeding times less the weight of any residual feed recorded for individual animals every morning. Steers were weighed at the beginning of the study and then every 30 days (successive periods) during the experiment. The means of the initial, final and successive body weights for each treatment were recorded throughout the trial at the same intervals to determine the ADG and FCR. 


\subsection{Rumen fermentation characteristics}

Ruminal fluid was sampled from sixteen steers at the end of the experiment using suction via the mouth. The tube was passed over the back of the tongue and into the oesophagus, and a vacuum pump was used to apply suction to draw the rumen liquid into the sampling bottle. Ruminal fluid samples were taken $4 \mathrm{hr}$ after the morning feeding. Ruminal fluid $\mathrm{pH}$ was measured immediately using a portable $\mathrm{pH}$ meter (Oakton $\mathrm{pH}$ Testr 30, USA). One millilitre of the rumen samples was centrifuged at 4,000×g for $10 \mathrm{~min}$ and the supernatant was analysed for ammonia nitrogen ( $\left.\mathrm{NH}_{3}-\mathrm{N}\right) \mathrm{using}$ the phenol-hypochlorite method modified from Weatherburn [30] with a spectrophotometer (Thermo Scientific, Helios Zeta ultraviolet-visible (UV-.VIS) model, USA). To determine VFAs, $1 \mathrm{~mL}$ ruminal fluid was mixed with $0.2 \mathrm{~mL}$ metaphosphoric acid solution and $40 \mu \mathrm{L}$ crotonic acid solution. After incubation overnight at $4{ }^{\circ} \mathrm{C}$, samples were centrifuged at $12,000 \times \mathrm{g}$ for $10 \mathrm{~min}$. The supernatant was collected for analysis using gas chromatography as described by Sawanon et al. [28].

\subsection{Carcass characteristics}

All Holstein crossbred steers were weighed at the end of the experiment (mean live weight \pm standard deviation, 635.41 $\pm 38 \mathrm{~kg} \mathrm{BW}$ and then deprived of feed but allowed free access to water before being humanely slaughtered after a fasting period of approximately $12 \mathrm{hr}$ according to Islamic tradition by severing the jugular veins, carotid arteries, trachea and the oesophagus. The blood was allowed to drain from the carcass. The weights of the intestine, rumen, reticulum, omasum and abomasum were recorded. Abdominal fat was removed from the abdomen and weighed. The fat covering the kidneys was removed and weighed. The warm carcass weight was taken shortly after slaughter. The $\mathrm{pH}$ level of the carcass was measured at $1 \mathrm{hr}, 24 \mathrm{hr}$ and 7 days post mortem from the muscles of the lumbar region (between the $4^{\text {th }}$ and $5^{\text {th }}$ lumbar vertebrae) using a portable meter with a penetrating electrode probe (TESTO205 pH meter; Testo Pty Ltd., Croydon South, VIC, Australia) according to the techniques of Orellana et al. [23]. After slaughtering, each carcass was divided into two equal longitudinal halves.

The back fat thickness was measured using callipers on the longissimus dorsi muscle between the $12^{\text {th }}$ and $13^{\text {th }}$ ribs at three-quarters of the length of the loin eye muscle from the chine (backbone) according to Orellana et al. [23].

The rib eye area was measured as the cut surface of the rib eye muscle between the $12^{\text {th }}$ and $13^{\text {th }}$ ribs by tracing the outline onto tracing paper and measuring the area using an LI-3100 Area Meter (LI-3100, Li-COR Biosciences, Lincoln, NE, USA) according to the methods of Cacere et al. [7].

The dressing percentage was measured after the carcass had been chilled at $0-4{ }^{\circ} \mathrm{C}$ for 7 days and then weighed to determine the cold carcass weight. The dressing percentage was calculated using the formula of dressing percentage $=$ (cold carcass weight $\times 100$ ) / live weight before slaughter [6].

The marbling score was evaluated by estimating the amount of intramuscular fat visible on the cut surface of the rib eye muscle between the $12^{\text {th }}$ and $13^{\text {th }}$ ribs using a photographic standard scale of five values $(1=$ devoid, $2=$ slight, $3=$ small, $4=$ moderate and $5=$ abundant) after chilling for 7 days according to the Thai Agricultural Commodity and Food Standard [22].

\subsection{Meat quality}

One kilogram of the longissimus dorsi muscle between the $12^{\text {th }}$ and $13^{\text {th }}$ ribs was sampled to determine meat quality after preservation at $0-4{ }^{\circ} \mathrm{C}$ for 7 day.

Meat colour was measured after the meat samples of the longissimus dorsi muscle were cut at a thickness of $2.5 \mathrm{~cm}$ and then exposed to air for $30 \mathrm{~min}$. After muscle oxygenation, the colour was measured using a colour meter (Hunter Lab Mini Scan EZ, 4500 L, Reston, VA, USA) to determine the colorimetric index of chromaticity. The components of L* (lightness), a* (red-green) and $\mathrm{b}^{*}$ (yellowness) are measured in the Hunter colour system and were assessed at three different points on the muscle surface [8].

The drip loss (\%) was evaluated from a meat sample with a $2.5 \mathrm{~cm}$ thickness that was weighed before storage (W1). The meat was then covered with a white cloth and hung at $2-4{ }^{\circ} \mathrm{C}$ for $24 \mathrm{hr}$. The meat weight was measured after storage (W2). The percentage of drip loss was calculated using the formula drip loss (\%) = (W1 - W2) × $100 / \mathrm{W} 1$ [4].

The thawing loss (\%) was evaluated from a meat sample with a $2.5 \mathrm{~cm}$ thickness that was kept at $-20^{\circ} \mathrm{C}$ for $24 \mathrm{hr}$ and then weighed (W1). The meat was defrosted to $4{ }^{\circ} \mathrm{C}$ having been frozen at $-20^{\circ} \mathrm{C}$ and then weighed (W1). The percentage of thawing loss was calculated using the formula thawing loss $(\%)=(\mathrm{W} 1-\mathrm{W} 2) \times 100 / \mathrm{W} 1$ [12]. 
The cooking loss (\%) was evaluated from a meat sample with a $2.5 \mathrm{~cm}$ thickness that was kept at $4{ }^{\circ} \mathrm{C}$ for $24 \mathrm{hr}$ and weighed before boiling (W1). The samples were placed in a plastic vacuum-sealed bag to protect the meat from steam forming inside the bag. The meat in the bag was cooked in hot steam until it reached a defined internal temperature of $72{ }^{\circ} \mathrm{C}$; then, it was removed from the steam and cooled to room temperature. The meat was weighed after boiling (W2) and the percentage of cooking loss was calculated using the formula cooking loss (\%) = (W1 - W2) $\times 100 / \mathrm{W} 1$ [12]

The shear force (SF) was evaluated after core samples for cooking loss were used to determine tenderness by measuring the Warner-Bratzler shear force (WBS). The sample was punched parallel to the muscle fibres using a steel hollow-core device with a diameter of $1.0 \mathrm{~cm}$ to obtain six pieces from each muscle sample. The shear force test was performed using a Warner-Bratzler Shear Device (Challion; GH Electronics Co.; San Francisco, CA, USA). The samples were sheared across the fibre axis using a V-shaped cutting blade with a shearing velocity of $20 \mathrm{~cm} / \mathrm{min}$. The WBS value from each muscle sample was recorded and the average value was used for evaluation [17].

Intramuscular fat was measured according to the methods of AOAC [3]. The meat samples were analysed after freezing $\left(-20^{\circ} \mathrm{C}\right)$. The frozen sample was weighed before being the meat was freeze-dried. The freeze-dried sample was weighed and ground and the fat content was quantified using solvent extraction (petroleum ether, BP $40-60{ }^{\circ} \mathrm{C}$ ) with a Soxhlet apparatus.

\subsection{Data analysis}

The data $(n=8)$ on feedlot performance and carcass characteristics and meat quality were subjected to Student $\mathrm{t}$-test. Differences in means were considered significant at $P<0.05$. Values between $P>0.05$ and $P \leq 0.10$ indicated a trend, while values of $P>0.10$ were not considered significant.

\section{Results}

\subsection{Growth performance}

The Holstein steers inoculated with cellulolytic R. albus KU-F152 and non-cellulolytic S. ruminantium S137 had a feed intake of $1.71 \%$ BW, which was not significantly different from control steers $(1.80 \% \mathrm{BW})$. The inoculated steers had mean values for final weight of $659.50 \mathrm{~kg}$, weight gain of $199.50 \mathrm{~kg}$ and average daily gain of $1.08 \mathrm{~kg} / \mathrm{d}$; these values were not significantly different from the control sample that had a final weight, weight gain and average daily gain of $631.33 \mathrm{~kg}, 171.17 \mathrm{~kg}$ and $0.93 \mathrm{~kg} / \mathrm{d}$, respectively. Moreover, $R$. albus KU-F152 and S. ruminantium S137 inoculation provided a FCR value for the steers of 9.72 that tended $(P=0.08)$ to be lower than that of the non-inoculated control with 10.11 (Table 2).

Table 2 Effect of cellulolytic Ruminococcus albus KU-F152 and non-cellulolytic Selenomonas ruminantium S137 supplementation on feedlot performance of Holstein crossbred steers.

\begin{tabular}{lllll}
\hline Item & Non-inoculated bacteria & Inoculated bacteria & SEM & $P$-value \\
\hline Initial weight (kg) & 460.16 & 459.50 & 21.83 & 0.49 \\
Feed intake (\%BW) & 1.80 & 1.71 & 0.07 & 0.25 \\
Final weight (kg) & 631.33 & 659.50 & 30.74 & 0.27 \\
Weight gain (kg) & 171.17 & 199.50 & 8.87 & 0.26 \\
Average daily gain (kg/d) & 0.93 & 1.08 & 0.14 & 0.26 \\
Feed conversion ratio & 10.11 & 9.72 & 0.69 & 0.08 \\
\hline
\end{tabular}

\subsection{Rumen fermentation characteristics}

Rumen $\mathrm{pH}$ and $\mathrm{NH}_{3}-\mathrm{N}$ values of steers inoculated with $R$. albus KU-F152 and S. ruminantium S137 were 6.77 and 4.14 mg \%, respectively, which were not significantly different to the $\mathrm{pH}(6.31)$ and $\mathrm{NH}_{3}-\mathrm{N}(4.58 \mathrm{mg} \%)$ of the control. The total VFA of the inoculated treatment (55.44 mM/L) was significantly higher than that of the non-inoculated control (36.49 mM/L). The acetate, propionate and butyrate ratios of the inoculated treatment group were 75.63:13.48:10.90, respectively, which were not significantly different to the control (Table 3). 
Table 3 Effects of cellulolytic Ruminococcus albus KU-F152 and non-cellulolytic Selenomonas ruminantium S137 supplementation on ruminal fermentation characteristics of Holstein crossbred steers.

\begin{tabular}{lllll}
\hline Item & Non-inoculated bacteria & Inoculated bacteria & SEM & $P$-value \\
\hline $\mathrm{pH}$ & 6.31 & 6.77 & 0.16 & 0.16 \\
$\mathrm{NH}_{3}-\mathrm{N} \mathrm{(mg \% )}$ & 4.58 & 4.14 & 0.37 & 0.42 \\
Total VFAs (mM/L) & 36.49 & 55.44 & 2.23 & 0.01 \\
Acetate (\%) & 71.78 & 75.63 & 2.69 & 0.29 \\
Propionate (\%) & 15.52 & 13.48 & 1.09 & 0.42 \\
Butyrate (\%) & 12.13 & 10.90 & 0.94 & 0.83 \\
Other (\%) & 1.52 & 1.94 & 0.21 & 0.14 \\
Acetate: Propionate ratio & 4.63 & 5.61 & 1.27 & 0.21 \\
\hline
\end{tabular}

\subsection{Carcass characteristics}

The marbling score of steers inoculated with $R$. albus KU-F152 and S. ruminantium S137 was 1.80, which tended to be higher $(P=0.06)$ than that of the non-inoculated control $(1.60)$. The back fat thickness, rib eye area, live weight at slaughter, hot carcass weight, dressing percentage, heart weight, liver weight, kidney weight, total fat, intestine weight, spleen weight, lung weight, rumen and reticulum weight, omasum weight, abomasum weight and stomach weight were not significantly different to the non-inoculated control (Table 4).

Table 4 Effect of cellulolytic Ruminococcus albus KU-F152 and non-cellulolytic Selenomonas ruminantium S137 supplementation on carcass characteristics of Holstein crossbred steers.

\begin{tabular}{lllll}
\hline Item & $\begin{array}{l}\text { Non-inoculated } \\
\text { bacteria }\end{array}$ & $\begin{array}{l}\text { Inoculated } \\
\text { bacteria }\end{array}$ & SEM & P-value \\
\hline Marbling score & 1.60 & 1.80 & 0.54 & 0.06 \\
Back fat thickness (cm) & 1.12 & 0.79 & 0.13 & 0.31 \\
Rib eye area $\left(\mathrm{cm}^{2}\right)$ & 51.83 & 57.09 & 5.38 & 0.61 \\
Live weight at slaughter $(\mathrm{kg})$ & 613.40 & 638.40 & 23.04 & 0.49 \\
Hot carcass weight $(\mathrm{kg})$ & 346.26 & 355.12 & 18.56 & 0.33 \\
Dressing percentage (\%) & 55.10 & 54.29 & 0.70 & 0.72 \\
Heart $(\mathrm{kg})$ & 2.22 & 2.30 & 0.16 & 0.48 \\
Liver $(\mathrm{kg})$ & 7.56 & 7.92 & 0.82 & 0.43 \\
Kidney $(\mathrm{kg})$ & 1.10 & 1.28 & 0.14 & 0.26 \\
Spleen $(\mathrm{kg})$ & 1.06 & 1.24 & 0.13 & 0.22 \\
Lung $(\mathrm{kg})$ & 4.84 & 5.62 & 0.44 & 0.77 \\
Kidney fat $(\mathrm{kg})$ & 18.54 & 16.34 & 2.83 & 0.74 \\
Total fat $(\mathrm{kg})$ & 55.26 & 51.90 & 8.27 & 0.40 \\
Intestine $(\mathrm{kg})$ & 11.56 & 11.28 & 1.50 & 0.18 \\
Rumen and reticulum $(\mathrm{kg})$ & 8.88 & 10.02 & 1.03 & 0.10 \\
Omasum $(\mathrm{kg})$ & 1.94 & 1.96 & 0.12 & 0.15 \\
Abomasum) $\mathrm{kg})$ & 2.16 & 2.23 & 0.31 & 0.50 \\
Stomach $(\mathrm{kg})$ & 12.98 & 14.30 & 0.93 & 0.97 \\
\hline
\end{tabular}




\subsection{Meat quality}

The meat $\mathrm{pH}$ values following inoculation with $\mathrm{R}$. albus KU-F152 and S. ruminantium S137 were in the range 5.82-5.83 after preservation at $0-4{ }^{\circ} \mathrm{C}$ for $24 \mathrm{hr}$ and 7 days, which were significantly higher than those of the non-inoculated control (5.57-5.62). The shear force and thawing loss of the inoculated treatments were $4.03 \mathrm{~kg}$ and $1.35 \%$, respectively, which were significantly lower than the control ( $4.68 \mathrm{~kg}$ and $1.73 \%$, respectively). Moreover, the meat fat $(15.10 \%)$ of the inoculated treatment tended to be higher than for the meat fat $(10.58 \%)$ of the non-inoculated control $(P \leq 0.09)$. The cooking loss and drip loss were not significantly different between the inoculated and control. Furthermore, the meat colour values of inoculated treatment were $43.42 \mathrm{~L}^{*}$ (lightness), 13.93 a* (redness) and 14.35 $\mathrm{b}^{*}$ (yellowness), which were higher than for the non-inoculated control $\left(39.18 \mathrm{~L}^{*}, 12.68 \mathrm{a}^{*}\right.$ and $\left.11.70 \mathrm{~b}^{*}\right)$ as shown in Table 5.

Table 5 Effect of cellulolytic Ruminococcus albus KU-F152 and non-cellulolytic Selenomonas ruminantium S137 supplementation on meat quality of Holstein crossbred steers

\begin{tabular}{lllll}
\hline Item & $\begin{array}{l}\text { Non-inoculated } \\
\text { bacteria }\end{array}$ & $\begin{array}{l}\text { Inoculated } \\
\text { bacteria }\end{array}$ & SEM & P-value \\
\hline pH at $1 \mathrm{hr}$ & 6.33 & 6.36 & 0.11 & 0.22 \\
pH at 24 hr & 5.62 & 5.82 & 0.10 & 0.03 \\
pH at 7 days & 5.57 & 5.83 & 0.12 & 0.03 \\
Shear force (kg) & 4.68 & 4.03 & 1.30 & 0.01 \\
Cooking loss (\%) & 30.90 & 35.46 & 2.33 & 0.25 \\
Drip loss (\%) & 2.23 & 1.94 & 0.31 & 0.52 \\
Thawing loss (\%) & 1.73 & 1.35 & 0.41 & 0.02 \\
Meat fat (\%) & 10.58 & 15.10 & 6.58 & 0.09 \\
Meat fat (\%DM) & 27.80 & 29.04 & 5.52 & 0.19 \\
Moisture meat (\%) & 62.76 & 65.20 & 1.61 & 0.45 \\
Meat colour & & & & 0.05 \\
L $^{*}$ & 39.18 & 43.42 & 2.08 & 0.87 \\
$\mathrm{a}^{*}$ & 12.68 & 13.93 & 1.00 & 0.04 \\
$\mathrm{~b}^{*}$ & 11.70 & 14.35 & 1.23 &
\end{tabular}

\section{Discussion}

The cellulolytic $R$. albus KU-F152 and non-cellulolytic $S$. ruminantium S137 supplementation had no negative effects on the feed intake, final weight, weight gain and ADG of Holstein steers. Prihantoro et al. [26] reported that the inoculation of ruminal bacterium increased the feed intake and ADG (19.47\%) of Holstein calves during the weaning period. In the current study, $R$. albus and S. ruminantium inoculation increased the final weight, weight gain and ADG compared to the non-inoculated control by $4.46 \%, 16.45 \%$ and $16.13 \%$, respectively. These results were due to $R$. albus KU-F152 and $S$. ruminantium S137 increasing the feed digestion efficiency [5, 27]. Similarly, Prihantoro et al. [26] reported that buffalo rumen bacteria resulted in a relative improvement in the feed digestive efficiency of Holstein calves during the weaning period. In the current study, $R$. albus KU-F152 and S. ruminantium S137 increased the total VFA content in the rumen fluid. This result was confirmed by Piamya et al. [24] who reported that the co-culture of $R$. albus KU-F152 and $S$. ruminantium S137 increased the total VFA concentration in vitro. The rumen microbial community plays an important role in carbohydrate fermentation and in providing energy to the host animal through VFAs [2]. The pH values in the rumen of the inoculated steers increased, indicating that $R$. albus KU-F152 and S. ruminantium S137 could improve rumen conditions. Similarly, Musa et al. [21] reported that rumen bacteria improved the pH conditions and microbial ecology in calf rumen.

$R$. albus and $S$. ruminantium inoculation increased the marbling score $(12.5 \%)$ of Holstein steers in the carcass characteristics of the current study. Similarly, Abbas et al. [2] reported that the rumen microbial community led to increased marbling by manipulating the rumen bacteria that create fermentation by-products of VFAs. Regarding the meat qualities in the current study, the bacterial inoculation showed the $\mathrm{pH}$ values after preservation at $0-4{ }^{\circ} \mathrm{C}$ for 24 
and 7 days were higher than those of the control. Meat that has high pH values can retain a larger amount of water, resulting in high juiciness, compared to that with low $\mathrm{pH}$ values [1]. Moreover, the meat of steers inoculated with $R$. albus KU-F152 and S. ruminantium S137 in the current study had a lower thawing loss and shear force than control meat and the decreased shear force resulted in enhanced meat tenderness (Table 5). Furthermore, inoculated steers had a higher meat fat percentage (42.72\%) and higher colour values of $\mathrm{L}^{*}$ (lightness) and $\mathrm{b}^{*}$ (yellowness) than the controls. Meat lightness is the first factor that consumers use as an indication of freshness [18]. These results suggested that $R$. albus and $S$. ruminantium supplementation in the rumen could improve the meat quality of dairy steers.

\section{Conclusion}

The inoculation of cellulolytic $R$. albus KU-F152 and non-cellulolytic $S$. ruminantium S137 had no effect on the feedlot performance of Holstein steers fed TMR; however bacteria supplementation increased the FCR compared to the control. Bacteria supplementation increased the ruminal total VFA, marbling score and meat fat and reduced the thawing loss. Furthermore, the meat following bacteria supplementation had a significantly lower shear force (tender meat) and a lighter colour than that of the control.

\section{Compliance with ethical standards}

\section{Acknowledgments}

This research was supported by The Thailand Research Fund (TRF), the Center for Advanced Studies for Agriculture and Food (CASAF), Kasetsart University Institute for Advanced Studies and the Kasetsart University Research and Development Institute (KURDI), Bangkok, Thailand.

\section{Disclosure of conflict of interest}

The authors declare there are no conflicts of interest.

\section{Statement of ethical approval}

This study was conducted at the animal farm of Kasetsart University in Thailand with the approval of Kasetsart University Animal Use Committee (ID number: ACKU 60-AGK-003).

\section{References}

[1] Aaslyng MD, Bejerholm, Ertbjerg P, Bertram HC and Andersen HJ. (2003). Cooking loss and juiciness of pork in relation to raw meat quality and cooking procedure. Food Quality and Preference, 14, 277-88.

[2] Abbas W, Knoell1 AL, Tom WA, Anderson CL, Paz1 HA and Fernando SC. (2018). Impact of rumen bacteria on marbling in Wagyu cattle. Journal of Animal Science, 96, 245-246.

[3] AOAC International. (2016). Official Methods of Analysis of AOAC International. 20th ed. Assoc. Off. Anal. Chem., Rockville, MD, USA.

[4] Barton-Gade PA, Demeyer D, Honikel KO, Joseph RL, Poulame E, Severini M, Smulder FJ and Tonberg E .(1993). Reference method for water holding capacity in Meat and Meat Products .Procedure recommended by an OECD working group. 39th International Congress of Meat Science and Technology. August 1-6, Calgary Alberta, Canada.

[5] Boonsaen P, Poonko S, Kanjanapruetipong J, Wongchawalit J, Phiriyangkul P and Sawanon S. (2019). Isolation and partial characterization of Ruminococcus flavefaciens from the rumen of swamp buffalo. Buffalo Bulletin, 38(2), 311-325.

[6] Boonsaen P, Soea NW, Maitreejeta W, Majarunea S, Reungprima T and Sawanon S. (2017). Effects of protein levels and energy sources in total mixed ration on feedlot performance and carcass quality of Kamphaeng Saen steers .Agriculture and Natural Resources, 51, 57-6.

[7] Cacere RAS, Morais MG, Alves FV, Feijó GLD, İtavo CCBF, İtavo LCV, Oliveira LB and Ribeiro CB. (2014). Quantitative and qualitative carcass characteristics of feedlot ewes subjected to increasing levels of concentrate in the diet .Arquivo Brasileiro de Medicina Veterinária e Zootecnia, 66, 1601-1610. 
[8] Caldara FR, Moi M, Santo LS, Almeida ICL, Paz RG, Garcianääs IA and Fernandes ARM. (2013). Carcass characteristics and qualitative attributes of pork from immunocastrated animals. Journal of Animal Science, 26, 1630-1636.

[9] Castells L, Bach A, Aris A and Terre M. (2013). Effects of for-ages provision for young calves on rumen fermentation and development of the gastrointestinal tract. Journal of Dairy Science, 96, 5226-5236.

[10] Choi SH, Wu G, Wickersham T, Choi CW and Smith SB. (2014). Abomasal infusion of arginine stimulates SCD and C/EBPß gene expression, and decreases CPT1ß gene expression in bovine adipose tissue independent of conjugated linoleic acid. Journal of Amino Acids, 46, 353-366.

[11] Dezfouli MRM, Tajik P, Bolourchi M and Mahmoudza-deh H. (2007). Effects of probiotics supplementation in daily milk intake of new born calves on body weight gain, body height, diarrhoea occurrence and health condition. Pakistan Journal of Biological Sciences, 10, 3136-3140.

[12] Eastridge JS and Bowker BC .(2011). Effect of rapid thawing on the meat quality attributes of USDA select beef strip loins steaks. Journal of Food Science, 76, 156-162.

[13] Flint HJ. (1997). The rumen microbial ecosystem some recent developments .Trends in Microbiology, 5, 483488.

[14] Fondevila M and Dehority BA. (1996) .Interactions between Fibrobacter succinogenes, Prevotella ruminicola and Ruminococcus flavefaciens in the digestion of cellulose from forages .Journal of Animal Science, 74, 678-684 .

[15] Frizzo LS, Soto LP, Zbrun MV, Bertozzi E, Sequiera G, Aimesto RR and Rosmini MR. (2010). Lactic acid bacteria to improve growth performance in young calves fed milk replacer and spry-dried whey powder. Animal Feed Science and Technology, 157, 159-167.

[16] Fukuma NM, Koike S and Kobayashi Y. (2015). Monitoring of gene expression in Fibrobacter succinogenes S85 under the co-culture with non-fibrolytic ruminal bacteria. Archives of Microbiology, 197, 269-276.

[17] Jaturasitha S, Norkeawa R, Vearasilp T, Wicke M and Kreuzer M .(2009) . Carcass and meat quality of Thai native cattle fattened on Guinea grass (Panicum maxima) or Guinea grass-legume (Stylosanthes guianensis) pastures, Meat Science, 81, 155-162.

[18] Joo ST, Kim GD, Hwang YH and Ryu YC. (2013). Control of fresh meat quality through manipulation of muscle fiber characteristics. Meat Science, 95(4), 828-36.

[19] Krause KM and Oetzel GR. (2006). Understanding and preventing subacute ruminal acidosis in dairy herds: A review. Animal Feed Science and Technology, 126, 215-236.

[20] Kumar B and Sirohi SK. (2013). Effect of isolate of ruminal fibrolytic bacterial structure supplementation on fibrolytic bacterial population and survivability of inoculate bacterial strain in lactating Murrah buffalos. Veterinary World, 6, 14-17.

[21] Musa HH, We SL, Zhu CH, Seri HI and Zhu GQ. (2009). The potential benefits of probiotics in animal production and health. Journal of Animal and Veterinary Advances, 8, 313-321.

[22] National Bureau of Agriculture Commodity and Food Standard. (2004). Thai Agricultural Commodity and Food Standard TACFS6001 :Beef .Ministry of Agriculture and Cooperatives, Bangkok, Thailand.

[23] Orellana C, Peña F, García A, Perea J, Martos J, Domenech V and Acero R.) 2009). Carcass characteristics, fatty acid composition, and meat quality of Criollo Argentino and Braford steers raised on forage in a semi-tropical region of Argentina. Meat Science, 81, 57-64.

[24] Piamya P, Hattakum C, Chiang HI and Sawanon S. (2017). Use of coculture cellulolytic Ruminococcus albus KUF152 and noncellulolytic Selenomonas ruminantium S137 for improving fiber digestibility and nutrition values of rice straw and para grass in in vitro ruminal fermentation. Buffalo Bulletin, 36(4), 639-652.

[25] Poonko S, Boonsaen P and Sawanon S. (2015). Fibrolytic bacterium isolated from buffalo rumen phylogenetically closely related to Butyrivibrios and Pseudobutyrivibrios. Kasetsart Journal Natural Science, 49, 547-559.

[26] Prihantoro I, Evvyernie D, Suryani S, Abdullah L and Toharmat T. (2014). Nutrient digestibility and performances of Frisian Holstein calves fed with Pennisetum purpureum and inoculated with buffalo's rumen bacteria. Media Peternakan, 37(3), 161-168. 
[27] Sawanon S and Kobayashi Y. (2006). Synergistic fibrolysis in the rumen by cellulolytic Ruminococcus flavefaciens and non-cellulolytic Selenomonas ruminantium: Evidence in defined cultures. Animal Science Journal, 77, 208214.

[28] Sawanon S, Koike S and Kobayashi Y. (2011). Evidence for the possible involvement of Selenomonas ruminantium in rumen fiber digestion. FEMS Microbiology Letters, 325, 170-179.

[29] Shinkai T and Kobayashi Y. (2007). Localization of ruminal cellulolytic bacteria on plant fibrous materials as determined by fluorescence in situ hybridization and real-time PCR. Applied and Environmental Microbiology, $73,1646-1652$.

[30] Weatherburn MW. (1967). Phenol-hypochlorite reaction for determination of ammonia. Analytical Chemistry, 39, 971-974.

[31] Wolin MJ, Miller TL and Stewart CS. (1997). Microbe interactions, In: Hobson, PN \& CS Stewart (eds). Handbook of the Rumen Microbial Ecosystem. London Blackie Academic and Professional Publishers, UK, 467-491.

[32] Wu RB, Munns K, Li JQ, John SJ, Wierenga K, Sharma R and McAllister TA. (2011). Effect of triticale dried distillers grains with soluble on ruminal bacterial populations as revealed by real time polymerase chain reaction. AsianAustralasian Journal of Animal Sciences, 24(11), 1552-1559.

\section{How to cite this article}

Hattakum C, Wongchawalit J, Thirawong P, Boonsaen P and Sawanon S. (2020). Effect of cellulolytic Ruminococcus albus KU-F152 and non-cellulolytic Selenomonas ruminantium S137 supplementation on feedlot performance, carcass characteristics and meat quality of Holstein crossbred steer. World Journal of Advanced Research and Reviews, 7(2), 104-114. 